\title{
Adaptive laboratory evolution of heat tolerance in Streptococcus thermophilus BIOPOP-1 and BIOPOP-2 under gradually increasing heat temperature
}

\section{Bonggyu Min}

Seoul National University College of Agriculture and Life Sciences

Kkotnim Kim

Seoul National University College of Agriculture and Life Sciences

Vladimir Li

Seoul National University College of Agriculture and Life Sciences

Younghoon Kim

Seoul National University College of Agriculture and Life Sciences

Heebal Kim ( $\nabla$ heebal@snu.ac.kr)

Seoul National University College of Agriculture and Life Sciences https://orcid.org/0000-0003-3064-1303

\section{Research article}

Keywords: Streptococcus thermophilus, Adaptation Laboratory Evolution, Heat tolerance, Cross protection, Freezing stability, Fatty acid composition Posted Date: September 9th, 2019

DOI: https://doi.org/10.21203/rs.2.14193/v1

License: (c) (i) This work is licensed under a Creative Commons Attribution 4.0 International License. Read Full License 


\section{Abstract}

Background Streptococcus thermophilus is one of the lactic acid bacteria (LAB), as such, has been commonly used in the production of fermented dairy foods during past decades. However, $\mathrm{LAB}$ including $\mathrm{S}$. thermophilus struggle to survive at temperatures above $60^{\circ} \mathrm{C}$, which are applied during manufacturing processes, such as pasteurization that can inhibit cell proliferation and promote cell death. Although there are many studies on $\mathrm{S}$. thermophilus, no research regarding its heat tolerance in over $60^{\circ} \mathrm{C}$ has been done yet. In this study, a method of adaptive laboratory evolution (ALE) was implemented in an attempt to increase the upper thermal threshold of two S. thermophilus strains of LAB found in South Korea.

Results To develop heat tolerant LABs, heat treatment was continuously applied to bacteria by increasing temperature from $60^{\circ} \mathrm{C}$ until the point of not being detected. The results indicated significant increase in temperature tolerance of ALE strains compared to the wild type (WT) strains. In addition, ALE strains acquired cross protection from various stress conditions like acid, bile salts and salinity. The improved heat tolerance of ALE strains showed higher survival rate during long term storage at sub-zero temperatures compared to the wild type strains. Fatty acid analysis indicated that saturated fatty acid ratio of ALE strains was higher than that of WT cells.

Conclusions The results of this study demonstrated that this ALE method can be utilized to improve bacterial tolerance against various environmental stresses. Adaptive evolution under heat stress might be applied in the various industries.

\section{Background}

Probiotics are living microorganisms whose inclusion in the diet intends to provide health benefits of the host by improving intestinal environment [1]. Lactic acid bacteria (LAB) belong to a class of probiotic bacteria that has been extensively used in food industries and especially dairy product industry. Probiotic bacteria include members of the genera Lactobacillus, Bifidobacterium, Enterococcus and Streptococcus [2].

Streptococcus thermophilus belongs to LAB class bacteria, and has been extensively used in the food industry [3]. During past decades, this species has been commonly used for the production of fermented dairy foods because it both enhances the flavor of dairy products, and accelerates the ratio of product acidification [4]. During industrial processes, bacteria mayexperience various environmental stresses such as low pH, high salinity and sub-zero temperatures. Heat stress has been one of the most widely studied topics of LAB [5]. As suggested by its name, S. thermophilus is thermophilic lactic acid bacteria. They have the ability to withstand relatively high temperatures. Unfortunately, higher temperatures $\left(>60^{\circ} \mathrm{C}\right)$ are sometimes required for certain manufacturing processes such as pasteurization, which can negatively affect bacterial growth and even lead to cell death [6]. This led to the increased interests in expanding bacterial abilities to survive under elevated environmental stress conditions, and many studies are dedicated to them [7]. To overcome those biological limitations, studies have focused on the Adaptive Laboratory Evolution (ALE) which is a method to gain insights into the basic mechanisms of molecular evolution in biological studies and adaptive changes that accumulate in microbial populations during long term selection under certain growth conditions [8]. This method has been used with great success to gain insights into the genetic basis and studying molecular evolution as well as adaptive changes in an adjusted laboratory setting [9]. ALE also has been successfully implemented in a useful method for obtaining microorganisms with particular traits. Recent studies have shown that limiting growth temperature at $42^{\circ} \mathrm{C}$ can be successfully overcome in bacteria such as E. coli and S. cerevisiae through ALE [10, 11].

This study aimed to implement ALE on two strains of $S$. thermophilus (BIOPOP-1 and BIOPOP-2), isolated from fermented dairy foods in South Korea to increase their upper heat tolerance limit, in order to survive at temperatures above $60^{\circ} \mathrm{C}$. The viability of the evolved bacteria was compared with that of WT strains. The possibilities of developing improved tolerance to additional stress conditions, such as low pH, bile and salinity were further assessed. The composition of fatty acids was analyzed and they were also put for storage under sub-zero conditions for 12 months. It was hypothesized that the evolved bacteria not only tolerate high temperature, but also can withstand various stress conditions, and this method can be applied in different industries.

\section{Results}

\section{Screening and phylogenetic analysis of the strains}

Strains were isolated from fermented dairy foods and appeared as Gram-positive and catalase-negative bacteria. Two globular-shaped strains BIOPOP-1 and BIOPOP-2 were selected after incubation at $50^{\circ} \mathrm{C}$ for $24 \mathrm{~h}$. Strain BIOPOP-1 demonstrated adequate survival and proliferation ratios, while strain BIOPOP-2 showed positive survival ratio, but near zero proliferation ratio.

The phylogenetic tree based on the $16 \mathrm{~S}$ rRNA gene sequences was built (Fig. 2). According to them, strains BIOPOP-1 and BIOPOP-2 were identified as $S$. thermophilus [12]. The 16S rRNA gene of strain BIOPOP-1 was matched 99.8\% with S. thermophilus type strain ATCC 19258 and strain BIOPOP-2's 16S rRNA gene was matched $99.25 \%$ with S. thermophilus type strain ATCC 19258 (Table S1) [13]. Although strains BIOPOP-1 and BIOPOP-2 were the same species, they showed completely different levels of natural heat tolerance.

\section{Increasing bacterial heat tolerance threshold by adaptive laboratory evolution}

The cells were subjected to ALE procedure by gradually elevating the basal $\left(60^{\circ} \mathrm{C}\right)$ temperature [14]. BIOPOP- 1 strain was able to withstand temperatures up to $84^{\circ} \mathrm{C}$, while BIOPOP-2 strain only survived up until $81^{\circ} \mathrm{C}$ was reached. The surviving bacteria were designated as $\mathrm{ALE}$ strains $\left(\mathrm{BIOPOP}-1: 84^{\circ} \mathrm{C}, \mathrm{BIOPOP}-2\right.$ : $\left.81^{\circ} \mathrm{C}\right)$.

To confirm the success of $A L E$, each temperature bacterium from $60^{\circ} \mathrm{C}$ to the final survival temperature of last heating named $A L E$ strain was cultured and subjected to the heat shock at $72^{\circ} \mathrm{C}$ for $1 \mathrm{~min} .72^{\circ} \mathrm{C}$ is a midpoint within acceptable temperature range for the both strains, and is a deciding criterion for using 
in the test. As a result, BIOPOP-1 strain demonstrated that $60^{\circ} \mathrm{C}$ strain was the lowest viability and the low viability was maintained up to $66^{\circ} \mathrm{C}$ strain. However, the viability was gradually increased from $69^{\circ} \mathrm{C}$ strain and $84^{\circ} \mathrm{C}$ (ALE) strain was the highest. (Fig $3(\mathrm{a})$ ). In case of BIOPOP-2 strain, cell viabilities were low up to $69^{\circ} \mathrm{C}$ strains, but it drastically increased from $72^{\circ} \mathrm{C}$ strain. And the highest viability data were recorded $81^{\circ} \mathrm{C}(\mathrm{ALE}) \mathrm{strain}(\mathrm{Fig} 3(\mathrm{~b})$ ).

\section{Viability comparison between WT and ALE strains}

\section{Heat shock with variable temperatures at set time}

Starting from basal $60^{\circ} \mathrm{C}$, cells were subjected to heat treatment with gradual temperature increment of $3^{\circ} \mathrm{C}$ every 1 min until final survival temperature was reached; $84^{\circ} \mathrm{C}$ for $\mathrm{BIOPOP}-1$ and $81^{\circ} \mathrm{C}$ for BIOPOP-2 correspondingly. BIOPOP- 1 strain showed no significant difference in cell viability between WT and $\mathrm{ALE}$ strains. Nevertheless, the viability of ALE strain was slightly higher than the WT sample. Upon reaching $84^{\circ} \mathrm{C}$, no viable WT cells were observed, while most of the ALE strain cells remained alive (Fig. 4(a)). In case of BIOPOP-2 strain, WT cells were not detected from temperature reached $75^{\circ} \mathrm{C}$, while the ALE strain were detected until reaching $81^{\circ} \mathrm{C}$ (Fig. $4(\mathrm{~b})$ ). Overall, the results demonstrated positive increment of heat tolerance in ALE strains compared to WT.

\section{Prolonged heat treatment at constant temperature}

Prior to the experiment, both WT and ALE strains were adapted at sub-lethal temperature, $52^{\circ} \mathrm{C}$ for 15 min. Studies showed that heat adapted LABs have higher viability ratio compared to non-adapted ones [15]. Microorganisms defined their heat tolerance by $D$ value (decimal reduction time) which is exposure time required to causes one $\log _{10}$ or $90 \%$ reduction of the initial population under specified temperature [16]. Based on the WT strains, D value of BIOPOP-1 at $60^{\circ} \mathrm{C}$ was $4.5 \mathrm{~min}$ and $1.1 \mathrm{~min}$ for BIOPOP-2.

The cell viability of adapted ALE strain was much higher than that of adapted WT cells for the most of the time. In case of strain BIOPOP-1, the results of WT strain and ALE strain were similar until reaching 10 min time period, when the number of viable WT cells started to gradually decrease, and no growth was detected at 50 min time limit, but ALE strain was still within the adequate values (Fig. 5(a)). Likewise, the viability of BIOPOP-2 showed that no growth of WT cells was detected from 40 min time period, while ALE strain remained alive until 50 min time limit (Fig. 5(b)). Thus, the overall results of this method positively correlate with the results of the first method, demonstrating stable positive increment towards heat survivability of ALE strains.

\section{ALE induced cross-protection enhancement against multiple environmental stresses}

The higher the heat tolerance, the stronger tolerance to other stresses by cross protection [17]. In order to confirm this, the strains with increased heat tolerance through ALE experiment were exposed to various stress environments such as acid, bile salt and salinity. Table 1 summarizes the results of cross-protection in these stress conditions.

\section{Acid tolerance}

Acid tolerance is one of the vital abilities of LABs necessary to survive in acidic environment of the stomach after being ingested [18]. The average pH of the stomach is $2 \sim 3$ and it takes about $2 \sim 3 \mathrm{~h}$ for food to move through the digestive tract [19]. WT and ALE strains were exposed MRS where the pH was adjusted to 2 and 3 . When exposed to $\mathrm{pH} 3$ for $2 \mathrm{~h}$, all strains showed that survival ratios were similarly high. The WT of BIOPOP-1 strain was $78.18 \%$ and WT of BIOPOP-2 was $69.81 \%$, while that of BIOPOP-1's ALE strain was $83.13 \%$ and strain BIOPOP-2 was $91.76 \%$. However, exposing bacteria to pH 2 for $2 \mathrm{~h}$ showed significant change in survival ratios that all strains were dramatically decreased than exposing bacteria to $\mathrm{pH} 3$. The survival ratio was that WT strain of both BIOPOP-1 and BIOPOP-2 was $0.002 \%$, while that of BIOPOP-1 ALE strain was $0.48 \%$ and BIOPOP- 2 was $0.53 \%$.

\section{Bile salts tolerance}

The ability of lactic acid bacteria to survive under bile salts environments is also important for probiotics [20]. Both WT and ALE strains were exposed to 0.5\% bile salts for consequent $3 \mathrm{~h}$. The survival ratio of BIOPOP-1 (WT) was $1.75 \%$ and BIOPOP-2 (WT) was $0.19 \%$, while that of BIOPOP-1 (ALE) was $71.82 \%$ and BIOPOP-2 (ALE) was $98.91 \%$. Cells were then exposed to $1.0 \%$ bile salts for 3 h, and while survival ratio of BIOPOP-1 (ALE) was $0.29 \%$ and BIOPOP-2 (ALE) was $0.28 \%$; WT cells were not detected at all. Thus, the results revealed the ALE strains also acquired improved bile tolerance by adaptive evolution induced by heat.

\section{Salinity tolerance}

One of the methods usually used for preserving foods is to increase osmotic pressure by supplementing salts such as $\mathrm{NaCl}$ or $\mathrm{KCl}$ [21]. To evaluate salt tolerance, WT and ALE strains were first exposed to MRS containing $10 \% \mathrm{NaCl}$ for $24 \mathrm{~h}$, and both strains demonstrated $100 \%$ survival ratio. When exposed to MRS containing $20 \% \mathrm{NaCl}$ for $2 \mathrm{~h}$, the survival ratio of BIOPOP-1 (WT) dropped to $10.88 \%$ and BIOPOP-2 (WT) to $5.35 \%$, while that of BIOPOP-1 (ALE) was $47.62 \%$ and BIOPOP-2 (ALE) was $29.34 \%$. Lastly, the bacteria were exposed to $20 \% \mathrm{NaCl}$ for $24 \mathrm{~h}$, and demonstrated the following survival ratios: BIOPOP-1 (WT): $0.29 \%$, BIOPOP-2 (WT): 0.16\%, and BIOPOP-1 (ALE): $6.63 \%$, BIOPOP-2 (ALE): $7.88 \%$. Again, these data positively correlate with the previous stress experiments. 


\section{[Table 1 near here]}

\section{Fatty acid composition}

The fatty acid composition and the ability of the cells to resist the above mentioned stresses are closely related. Many researches have shown that lowering concentration of unsaturated fatty acids (UFAs) or increasing concentration of saturated fatty acids (SFAs) is decreased membrane fluidity and related to higher heat tolerance[15,21,22]. S. thermophilus BIOPOP-1 (WT)'s membrane is made of seven fatty acids and that of ALE strain consists of eight fatty acids. Also, membrane of BIOPOP-2 (WT) is made of six fatty acids and that of ALE strain is composed of seven fatty acids. They were divided into two groups: saturated fatty acids and unsaturated fatty acids [15]. The fatty acid compositions for all WT and ALE strains are summarized details in Table 2. When we compared fatty acid composition of WT and ALE strains, the total saturated fatty acid (SFAs) concentration of BIOPOP-1 (ALE) strain was slightly higher that of WT strain, $42.47 \%$ and $45.0 \%$ correspondingly. In contrast, the total unsaturated fatty acid (UFAs) concentration decreased $57.53 \%$ for WT cells and $55.0 \%$ for ALE strain. In case of BIOPOP-2, the total SFAs concentration of ALE strain was higher (30.79\%) than that of WT strain (23.07\%). On the contrary, the total UFAs concentration of ALE was $69.21 \%$ and it was less than WT (76.93\%). Also, different contents of hexanoic acid (C6:0) between WT and ALE strains were observed. Although, WTs of BIOPOP-1 and BIOPOP-2 could not be analyzed in regards of hexanoic acid, ALE strains were analyzed. As a result, both BIOPOP-1 and BIOPOP-2 featured increased ratios for saturated fatty acids, and reduced for unsaturated fatty acids. By analyzing these results, it can be observed with the increased ratio between SFA/UFA, tolerance to various stresses also increases [24].

\section{[Table 2 near here]}

\section{Stability to freezing and frozen storage}

After isolated from samples (WT strains) and completion of ALE experiment (ALE strains), the strains with 40\% glycerol were prepared as stocks (1:1, 500ul) and stored at $-80^{\circ} \mathrm{C}$. Cell viability was checked bimonthly for the period of 12 months. ALE strains demonstrated higher viability ratio than WT cells after 12 months period. In the case of BIOPOP-1, the vitality of WT cells similar with ALE stain and gradually decreased after 8 months, while ALE strain cells maintained approximately the same level. Upon reaching 12 months period, the difference in viability was getting large between WT and ALE strains (Fig. $6(a))$. In the case of BIOPOP-2, the viability of the WT strain was higher than ALE strain when they were first isolated. However, the viability of WT decreased rapidly after 2 months and maintained the low viability up until the 12th month. But after 2 months, the viability of ALE strain was higher than that of WT and maintained until the12th month (Fig. 6(b)). Therefore, ALE also increased the storage stability of bacteria when being frozen.

\section{Discussion}

Heat tolerance is one of the most important abilities of LABs necessary to survive during manufacturing processes, such as food fermentation or pasteurization, in which they can be exposed to high temperatures (up to $60^{\circ} \mathrm{C}$ ) [6]. One study showed that heat tolerant Escherichia coli were developed using ALE method by continuously cultivating the bacteria at $48.5^{\circ} \mathrm{C}$ [25]. In another study, researchers were able to increase the survival temperature of Corynebacterium glutamicum from $33^{\circ} \mathrm{C}$ to $41.5^{\circ} \mathrm{C}$ [26]. However, very few studies about manipulating tolerance of $S$. thermophilus strains through ALE exist, and no studies have been done dedicated to manipulating the bacteria's heat tolerance in over $60^{\circ} \mathrm{C}$.

In this study, bacterial strains with elevated heat tolerance threshold were developed using ALE method. Several probiotic strains primarily isolated from fermented dairy foods in South Korea and two $S$. thermophilus of LABthat were able to survive at $50^{\circ} \mathrm{C}$ for $24 \mathrm{~h}$ were selected for this study. These two strains showed the difference that inherently high heat tolerance (BIOPOP-1) and those having low heat tolerance (BIOPOP-2) when cultured at $50^{\circ} \mathrm{C}$. The growth of strain BIOPOP-1 was able to proliferate well, while BIOPOP-2 survived but hardly grew. This explains that strains of the same species can have different thresholds of heat tolerance. The adaptive laboratory evolution method was applied to the bacteria by gradually increasing the temperature and the final surviving bacteria were designated ALE strains.

Figure 3 shows that detectable changes in both strains started $72^{\circ} \mathrm{C}$ strains, and increased until achieving $84^{\circ} \mathrm{C}$ for $\mathrm{BIOPOP}-1$, and $81^{\circ} \mathrm{C}$ for $\mathrm{BIOPOP}-2$. Significant difference in the readings observed between start $\left(60^{\circ} \mathrm{C}\right)$ and each end (BIOPOP $\left.-1: 84^{\circ} \mathrm{C}, \mathrm{BIOPOP}-2: 81^{\circ} \mathrm{C}\right)$ strains, suggesting that bacteria increased heat tolerance to a greater extent. It is theorized that the evolutionary shifts of both strains were triggered around temperature points over $70^{\circ} \mathrm{C}$.

Two types of heat treatment experiments to compare viability between WT and ALE strains conducted and the overall results matched with the hypothesis that the viabilities of ALE strains were relatively higher than those of WT strains (fig. 4 and 5). Also, WT strains were completely absent during the final stage of each experiment, whereas ALE strain cells remained alive. In case of BIOPOP-1, general viability of ALE strain was higher than that of WT strain, but there was no significant difference in the values between WT and ALE. However, in case of BIOPOP-2, the heat tolerance of ALE strain increased substantially, and the results being significantly different compared to WT cells. In addition, an interesting observation was revealed that a strain with lower basal heat tolerance (BIOPOP-2) could extend its upper threshold by a greater value, while strain with higher basal heat tolerance (BIOPOP-1) would raise its upper limit to a very marginal extent. It might be considered that all bacteria have certain capacity to increase their stress tolerance limit. The lower the base values, the higher will the increment be, and higher based values mean there is less room for expansion.

Cross-protection is based on mechanism that closely related responses are generated by different stress conditions [17]. In other words, different types of stresses lead to a common or similar type of response, as well as specific response by some stresses [27]. The strains in this study also expanded their crossprotection against multiple stress conditions such as high acidity, bile and salinity as a result of ALE compared to WT strains. Probiotics must withstand multiple stress conditions to be able to colonize a colon of human in abundant numbers [28]. Before reaching the intestinal tract, probiotic bacteria must first 
survive acidic environment of the stomach generated by gastric juice [12]. In this experiment, ALE strains exhibited higher level of acid tolerance than the control group. Upon reaching the intestine, probiotic bacteria face with another challenge, which is bile salts. It was confirmed that ALE strains grew better than WT cells when they were exposed to $0.5 \%$ and $1 \%$ bile salts for $3 \mathrm{~h}$. Lactic acid bacteria can also be exposed to osmotic pressure during manufacture processes when additives such as salt or sugar are added to the product. Osmotic changes in the environment could rapidly damage essential cell functions, and bacteria need to adapt to such a change in order to survive [29]. They were exposed to $20 \% \mathrm{NaCl}$ for $2 \mathrm{~h}$ and $24 \mathrm{~h}$, and ALE strain again demonstrated higher level of stress tolerance than WT cells. Overall, the bacteria became more tolerate to the above mentioned stress conditions they might face during manufacturing and ingestion processes.

The analysis of fatty acid contents was carried out to determine the cause of increased heat tolerance. Constant heat shock to cells induced their heat tolerance enhancement, and this is clearly linked to modifications in membrane fatty acid composition [30]. In other words, it suggests that composition of the cellular fatty acids plays an important role in the response to heat stress in these strains. The results clearly indicate an increase in saturation level of fatty acids (SFA) as a response to being exposed to high temperatures (Table 2.). The SFA enhances acyl-chain packing in the membrane, and thus increases van der Waal interactions between the chains, which consequently leads to decreased membrane fluidity [31]. And this raises its ability to withstand multiple stresses. The amount of SFAs capable of increasing acyl-chain packing in the cell membrane is considered to be one of the most important factors for successful growth under various stress environments [5].

Lastly, lactic acid bacteria are exposed to low temperatures during industrial processes such as freezing and refrigerated storage [29], during which stabilized viability of LAB may contribute to the industries such as the storage of the products and the prolonged conservation conditions. One study identifies that heat tolerance of L. plantarum is also related to cold stress response [32]. In order to identify whether tolerance of ALE strains during freezing storage was improved by heat induced ALE, both WT and ALE strains were stored at $-80^{\circ} \mathrm{C}$ for 12 months. Figure 6 shows that ALE strains were more stable to freezing than WT. Through these results, increased heat tolerance also positively affected bacterial ability to be stored in frozen condition.

\section{Conclusion}

In this study, it was discovered that heat tolerant $S$. thermophilus ALE strains can be obtained through ALE procedure. Heat tolerance of ALE strains was higher than that of WT strains and exhibited higher tolerance to other stress conditions like acid, bile salts and salinity. Also, the modified bacteria became more stable to sub-zero temperatures, experienced during long term storage at $-80^{\circ} \mathrm{C}$. However, the exact molecular mechanisms are poorly understood and require further studies [17]. This method proved to be useful in the dairy industry, and can definitely be utilized in various industries.

\section{Methods}

\section{Isolation and selection of heat tolerant bacterial strains}

Several strains were isolated from fermented dairy foods in South Korea and only 8 catalase negative and Gram-positive isolates were selected [12]. They were cultured in sterile deMan Rogosa Sharpe medium (MRS, Difco, Becton Dickinson Co., Sparks, MD, USA) and incubated at $37^{\circ} \mathrm{C}$ for $24 \mathrm{~h}$. In order to identify latent heat tolerant strains, cells were incubated at $50^{\circ} \mathrm{C}$ for $24 \mathrm{~h}$ and two surviving isolates were selected. The cells were labeled as BIOPOP-1 and BIOPOP-2 and stored as stock samples in $40 \%$ glycerol at $-80^{\circ} \mathrm{C}$ [33].

\section{Identification of the isolates with 16S rRNA sequencing}

BIOPOP-1 and BIOPOP-2 strains were identified using 16S rRNA sequencing method. Genomic DNA was extracted according to the instruction provided by the manufacturer of DNA extraction kit (QIAGEN, USA) [12]. The 16S rRNA gene was amplified using the universal bacterial primer sets: 27F 5' (AGA GTT TGA TCM TGG CTC AG) 3' and 1492R 5' (TAC GGY TAC CTT GTT ACG ACT T) 3'[34]. Amplified PCR products were sent for sequencing (Macrogen, South Korea) and then results were used for assigning taxonomy using EZ-Biocloud server [35]. The phylogenetic trees were built based on the 16S rRNA gene sequences using the neighbor-joining methods by the MEGA X software [36]. The 16S rRNA gene sequences of 12 Streptococci strains and one Lactococcus lactis for using as out group were downloaded from the National Center for Biotechnology Information (NCBI) database.

\section{Adaptive laboratory evolution procedure}

Two strains of $S$. thermophilus (BIOPOP-1 and BIOPOP-2) were the starting material for the experiment [5]. Cultures from the stocks were streaked on the MRS agar plate and incubated at $37^{\circ} \mathrm{C}$ for $48 \mathrm{~h}$. Each colony was isolated and transferred to $10 \mathrm{ml} \mathrm{MRS}$ and incubated at $37^{\circ} \mathrm{C}$ for $24 \mathrm{~h}$. After incubation, $10 \mu \mathrm{l}$ of each sample was transferred to $1.5 \mathrm{ml}$ micro tube with $990 \mu \mathrm{l}$ MRS broth pre-heated at test temperature and heat treatment was performed in a dry bath for 1 min. Samples were cooled down for $5 \mathrm{~min}$ at room temperature, and incubated at $37^{\circ} \mathrm{C}$ for $24 \mathrm{~h}$. This procedure was repeated two more times and then the temperature was increased by $3^{\circ} \mathrm{C}$. Repeated incremental heat treatment was performed starting from $60^{\circ} \mathrm{C}$ until the point all bacteria were not detected. The process of this experiment is outlined on Fig 1. Samples were collected the third day's heat shock strains after $24 \mathrm{~h}$ incubation at each temperature for measuring changes in heat tolerance at every temperature point [37]. Collected samples then were stored at $-80^{\circ} \mathrm{C}$ in $40 \%$ glycerol as stock solutions and the final surviving strains were designated as ALE strains.

\section{Identification of heat tolerance enhancement}


The stocks of each temperature sample collected in the above step were thawed at room temperature and streaked on MRS agar plates. They were incubated at $37^{\circ} \mathrm{C}$ for $48 \mathrm{~h}$ and then each single colony was individually transferred to tubes with $10 \mathrm{ml}$ MRS broth and incubated at $37^{\circ} \mathrm{C}$ for $24 \mathrm{~h}$. $10 \mu \mathrm{l}$ of each sample was transferred to $1.5 \mathrm{ml}$ micro tube with $990 \mu \mathrm{l}$ MRS broth pre-heated at $72^{\circ} \mathrm{C}$ and heated for 1 min using a dry bath. After the heat treatment, they were cooled down for about $5 \mathrm{~min}$ at room temperature. Samples were serially diluted with $0.85 \%$ saline, then spread on MRS agar plates and incubated at $37^{\circ} \mathrm{C}$ for $48 \mathrm{~h}$.

\section{Viability comparison between WT and ALE strains}

\section{Heat treatment with variable temperatures at the set time}

The stocks of WT and ALE strains were thawed at room temperature and streaked on agar plates. After incubated the plates at $37^{\circ} \mathrm{C}$ for $48 \mathrm{~h}$, isolated single colonies of each plate were transferred into test tubes with $10 \mathrm{ml}$ of MRS and incubated at $37^{\circ} \mathrm{C}$ for $24 \mathrm{~h}$. Heat treatment was performed in dry bath with base temperature set to $60^{\circ} \mathrm{C}$ for both WT and ALE strains, temperature increment was $3^{\circ} \mathrm{C}$ until final survival temperature was reached for each sample. Cells were inoculated in MRS broth $(10 \mu$ cells, $990 \mu \mathrm{l}$ media) at each temperature point from 60 to final survived temperature of each strains and heated for 1 min. They were then serially diluted with $0.85 \%$ saline and transferred on MRS agar plate and incubated at $37^{\circ} \mathrm{C}$ for $48 \mathrm{~h}$.

\section{Prolonged heat treatment at constant temperature}

Subcultures of WT and ALE strains were prepared using the prepared in the upper step. Cells were exposed to sub-lethal temperature $\left(52^{\circ} \mathrm{C}\right.$ for 15 min) prior to the experiment. They inoculated $100 \mathrm{ul}$ into $10 \mathrm{ml}$ pre-heated MRS broth and heated in a water bath at $60^{\circ} \mathrm{C}$ from 0 to $50 \mathrm{~min} 100 \mu \mathrm{l}$ of the cells were transferred to tubes with $10 \mathrm{ml}$ pre-heated MRS broth[15]. The survival ratio was checked every $10 \mathrm{~min}$. After heat treatment, they were left to cool down for $5 \mathrm{~min}$ at room temperature. Cells then were serially diluted with $0.85 \%$ saline and spread on MRS agar plates and incubated at $37^{\circ} \mathrm{C}$ for $48 \mathrm{~h}$.

\section{Assessment of enhancement the ability of cross-protection after ALE procedure}

The cells were pre-cultured and cultured at $37^{\circ} \mathrm{C}$ for $24 \mathrm{~h}$. Cells were then harvested by centrifugation $\left(4,000 \mathrm{rpm}, 10 \mathrm{~min}\right.$, and $\left.4^{\circ} \mathrm{C}\right)$. They were washed twice with phosphate-buffered saline (PBS) with $\mathrm{pH}$ 7.0. To measure response against acid, cell pellets were re-suspended with MRS adjusted to 2 and 3 . Cell suspensions were incubated at $37^{\circ} \mathrm{C}$ for $2 \mathrm{~h}$. To evaluate their viability, they were serially diluted and spread on MRS agar plates, then incubated at $37^{\circ} \mathrm{C}$ for 48 h.

Bile salt tolerance of each strain was examined. Cells were harvested following the same protocol as in the previous experiment and re-suspended by MRS containing $0.5 \%$ and $1 \%$ bile salts (cholic acid sodium salt $50 \%$ and deoxycholic acid sodium salt $50 \%$, Sigma Aldrich, 48305 ). Cell suspensions were incubated at $37^{\circ} \mathrm{C}$ for $3 \mathrm{~h}$. Then serially diluted, spread on MRS agar plates and incubated at $37^{\circ} \mathrm{C}$ for $48 \mathrm{~h}$.

To assess salinity tolerance, bacteria were harvested following the same protocol as in the previous experiment. Cell pellets were then re-suspended by MRS containing $20 \% \mathrm{NaCl}$ (Sodium chloride, $99.5 \%$ ). Cell suspensions were incubated at $37^{\circ} \mathrm{C}$ for $2 \mathrm{~h}$ and $24 \mathrm{~h}$, serially diluted, then spread on MRS agar plates and incubated at $37^{\circ} \mathrm{C}$ for $48 \mathrm{~h}$. The survival ratio was calculated by dividing CFUs for both control and test cultures [38].

\section{Analysis of fatty acids content of bacterial membrane}

Fatty acids analysis was performed according to the method outlined by Garces and Mancha [39]. Cells were then harvested by centrifugation and washed twice with distilled water. Pellets were transferred to tubes with Teflon-lined caps and pentadecenoic acid (15:0) was used as an internal standard. Samples were mixed with methylation mixture containing methanol, benzene, DMP (2, 2-Dimethoxy-propane), sulfuric acid $\left(\mathrm{H}_{2} \mathrm{SO}_{4}\right)$ and heptane. For lipid extraction tubes were placed in a water bath at $80^{\circ} \mathrm{C}$ for $2 \mathrm{~h}$. They were then cooled down at room temperature. Samples were shaken and they split into two phases. The top layer containing FAMEs was extracted and analyzed using Agilent 7890A gas chromatography (Agilent, USA) equipped with a flame ionization detector (FID) and a DB-23 column (60mmx0.25mmx0.25um) (Agilent Technologies, Inc., Wilmington, DE). GC settings: injector temperature 250 ${ }^{\circ} \mathrm{C}$, split ratio $10: 1$, carrier flow $1.2 \mathrm{~mL} / \mathrm{min}$, detector temperature $280^{\circ} \mathrm{C}$, air flow in detector $350 \mathrm{~mL} / \mathrm{min}$, hydrogen flow $35 \mathrm{~mL} / \mathrm{min}$. The results were shown as relative percentages of each fatty acid and the ratios of saturated fatty acids (SFAs) and unsaturated fatty acids (UFAs) were calculated [15].

\section{Stability to freezing and long-term storage in frozen state}

Samples from original cultures or ALE procedure were stored in $40 \%$ glycerol at $-80^{\circ} \mathrm{C}$ as stock samples. After 2 months $100 \mu l$ were inoculated into $10 \mathrm{ml}$ of MRS broth ( $1 \%$ ) and incubated at $37^{\circ} \mathrm{C}$ for $24 \mathrm{~h}$. They were then serially diluted and spread on MRS agar plates to assess their viability. They were incubated at $37^{\circ} \mathrm{C}$ for $48 \mathrm{~h}$. This procedure was repeated every 2 months until 12 months period was reached.

\section{Statistical analysis}

All experiments were conducted three times. The Colony-Forming Units (CFUs) were counted and the viability was calculated by dividing CFUs for both control and test cultures [38]. The results were indicated as mean $\pm S D$ (standard deviation) [20]. Independent t-tests for statistical analyses were performed using $\mathrm{R}$ software and $P$-value was considered statistically significant $(P<0.05)[12]$ 


\section{List Of Abbreviations}

ALEAdaptive Laboratory Evolution

WTWild Type

LABLactic Acid Bacteria

CFUColony-Forming Units

MRSdeMan Rogosa Sharpe

rRNAribosomal RNA

UFAUnsaturated Fatty Acids

SFASaturated Fatty Acids

FAMEFatty Acid Methyl Esters

\section{Declarations}

\section{Authors' contributions}

H. B. K. designed the experiment, managed and supervised the project, B. G. M. designed the experiment, performed experiment, analyzed data, and prepared manuscript, K. N. K. designed and assisted with the experiment, V. L. and Y. H. K. assisted with editing of the manuscript. All authors read and approved the final version of the manuscript.

\section{Competing interests}

The authors declare that they have no competing interests

\section{Acknowledgements}

Not applicable

\section{Authors' information}

ORCID

Heebal Kimhttps://orcid.org/0000-0003-3064-1303

Younghoon Kimhttps://orcid.org/0000-0001-6769-0657

\section{References}

1. Fao \& Who, Fao Who. Health and Nutritional Properties of Probiotics in Food including Powder Milk with Live Lactic Acid Bacteria. C\{ó\}rdoba, Argentina Oct. 2001

2. Buntin N, Chanthachum S, Hongpattarakere T. Screening of lactic acid bacteria from gastrointestinal tracts of marine fish for their potential use as probiotics. Songklanakarin J Sci Technol. 2008.

3. Lorenzo JM, Munekata P, Dominguez R, Pateiro M, Saraiva JA, Franco D. Main Groups of Microorganisms of Relevance for Food Safety and Stability: General Aspects and Overall Description. In: Innovative technologies for food preservation inactivation of spoilage and pathogenic microorganisms. 2017.

4. Cui Y, Xu T, Qu X, Hu T, Jiang X, Zhao C. New insights into various production characteristics of streptococcus thermophilus strains. International Journal of Molecular Sciences. 2016.

5. Chen J, Shen J, Ingvar Hellgren L, Jensen PR, Solem C. Adaptation of Lactococcus lactis to high growth temperature leads to a dramatic increase in acidification rate. Sci Rep. 2015.

6. Angela L, Giuseppe S. Stress Responses of LAB. In: Paramithiotis S, Patra JK, editors. Food molecular microbiology. Boca Raton, U.S: CRC Press; 2019. p. 164-74.

7. Torres-Maravilla E, Lenoir M, Mayorga-Reyes L, Allain T, Sokol H, Langella P, et al. Identification of novel anti-inflammatory probiotic strains isolated from pulque. Appl Microbiol Biotechnol. 2016

8. Dragosits M, Mattanovich D. Adaptive laboratory evolution - principles and applications for biotechnology. Microbial Cell Factories. 2013.

9. Portnoy VA, Bezdan D, Zengler K. Adaptive laboratory evolution-harnessing the power of biology for metabolic engineering. Current Opinion in Biotechnology. 2011. 
10. Sandberg TE, Pedersen M, Lacroix RA, Ebrahim A, Bonde M, Herrgard MJ, et al. Evolution of escherichia coli to $42^{\circ} \mathrm{C}$ and subsequent genetic engineering reveals adaptive mechanisms and novel mutations. Mol Biol Evol. 2014.

11. Caspeta L, Chen Y, Ghiaci P, Feizi A, Baskov S, Hallström BM, et al. Altered sterol composition renders yeast thermotolerant. Science (80-). 2014.

12. Guo L, Li T, Tang Y, Yang L, Huo G. Probiotic properties of enterococcus strains isolated from traditional naturally fermented cream in China. Microb Biotechnol. 2016.

13. Ghattargi VC, Nimonkar YS, Burse SA, Davray D, Kumbhare S V., Shetty SA, et al. Genomic and physiological analyses of an indigenous strain, Enterococcus faecium 170M39. Funct Integr Genomics. 2018.

14. Caspeta L, Chen Y, Nielsen J. Thermotolerant yeasts selected by adaptive evolution express heat stress response at $30{ }^{\circ} \mathrm{C}$. Sci Rep. 2016.

15. Shin YJ, Kang CH, Kim W, So JS. Heat Adaptation Improved Cell Viability of Probiotic Enterococcus faecium HL7 upon Various Environmental Stresses. Probiotics and Antimicrobial Proteins. 2018.

16. Mazzola PG, Penna TCV, da S Martins AM. Determination of decimal reduction time (D value) of chemical agents used in hospitals for disinfection purposes. BMC Infect Dis. 2003.

17. Wang C, Cui Y, Qu X. Mechanisms and improvement of acid resistance in lactic acid bacteria. Archives of Microbiology. 2018.

18. Álvarez-Ordóñez A, Begley M, Prieto M, Messens W, López M, Bernardo A, et al. Salmonella spp. survival strategies within the host gastrointestinal tract. Microbiology. 2011.

19. Maragkoudakis PA, Zoumpopoulou G, Miaris C, Kalantzopoulos G, Pot B, Tsakalidou E. Probiotic potential of Lactobacillus strains isolated from dairy products. Int Dairy J. 2006.

20. Lee KW, Shim JM, Park SK, Heo HJ, Kim HJ, Ham KS, et al. Isolation of lactic acid bacteria with probiotic potentials from kimchi, traditional Korean fermented vegetable. LWT - Food Sci Technol. 2016.

21. Abee T, Wouters JA. Microbial stress response in minimal processing. Int J Food Microbiol. 1999.

22. Álvarez-Ordóñez A, Fernández A, López M, Arenas R, Bernardo A. Modifications in membrane fatty acid composition of Salmonella typhimurium in response to growth conditions and their effect on heat resistance. Int J Food Microbiol. 2008.

23. Sampathkumar B, Khachatourians GG, Korber DR. Treatment of Salmonella enterica serovar Enteritidis with a sublethal concentration of trisodium phosphate or alkaline pH induces thermotolerance. Appl Environ Microbiol. 2004.

24. Beal C, Fonseca F, Corrieu G. Resistance to Freezing and Frozen Storage of Streptococcus thermophilus Is Related to Membrane Fatty Acid Composition. J Dairy Sci. 2010.

25. Rudolph B, Gebendorfer KM, Buchner J, Winter J. Evolution of Escherichia coli for growth at high temperatures. J Biol Chem. 2010.

26. Oide S, Gunji W, Moteki Y, Yamamoto S, Suda M, Jojima T, et al. Thermal and Solvent Stress Cross-Tolerance Conferred to Corynebacterium glutamicum by Adaptive Laboratory Evolution. Appl Environ Microbiol. 2015.

27. Kim WS, Perl L, Park JH, Tandianus JE, Dunn NW. Assessment of stress response of the probiotic Lactobacillus acidophilus. Curr Microbiol. 2001.

28. Henriksson A, Khaled AKD, Conway PL. Lactobacillus colonization of the gastrointestinal tract of mice after removal of the non-secreting stomach region. Microb Ecol Health Dis. 1999.

29. Van de Guchte M, Serror P, Chervaux C, Smokvina T, Ehrlich SD, Maguin E. Stress responses in lactic acid bacteria. Antonie van Leeuwenhoek, Int J Gen Mol Microbiol. 2002.

30. Álvarez-Ordóñez A, Fernández A, López M, Bernardo A. Relationship between membrane fatty acid composition and heat resistance of acid and cold stressed Salmonella senftenberg CECT 4384. Food Microbiol. 2009.

31. Fulco AJ. Fatty acid metabolism in bacteria. Progress in Lipid Research. 1983.

32. De Angelis M, Di Cagno R, Huet C, Crecchio C, Fox PF, Gobbetti M. Heat Shock Response in Lactobacillus plantarum. Appl Environ Microbiol. 2004.

33. Desmond C, Stanton C, Fitzgerald GF, Collins K, Paul Ross R. Environmental adaptation of probiotic lactobacilli towards improvement of performance during spray drying. In: International Dairy Journal. 2002.

34. Devereux R, Willis SG. Amplification of ribosomal RNA sequences. In: Molecular Microbial Ecology Manual. 2011.

35. Kim O-S, Cho Y-J, Lee K, Yoon S-H, Kim M, Na H, et al. Introducing EzTaxon-e: a prokaryotic 16S rRNA gene sequence database with phylotypes that represent uncultured species. Int J Syst Evol Microbiol. 2012.

36. Kumar S, Stecher G, Li M, Knyaz C, Tamura K. MEGA X: Molecular evolutionary genetics analysis across computing platforms. Mol Biol Evol. 2018.

37. Barrick JE, Yu DS, Yoon SH, Jeong H, Oh TK, Schneider D, et al. Genome evolution and adaptation in a long-term experiment with Escherichia coli. Nature. 2009.

38. Shibai A, Takahashi Y, Ishizawa Y, Motooka D, Nakamura S, Ying BW, et al. Mutation accumulation under UV radiation in Escherichia coli. Sci Rep. 2017.

39. GarcÉs R, Mancha M. One-step lipid extraction and fatty acid methyl esters preparation from fresh plant tissues. Anal Biochem. 1993.

\section{Tables}


Table 1. The results of cross protection against acid, bile salt and salinity condition.

\begin{tabular}{|c|c|c|c|c|c|c|c|c|c|c|c|c|c|}
\hline & & \multicolumn{5}{|l|}{ Acid } & \multicolumn{5}{|l|}{ Bile Salt } & \multicolumn{2}{|l|}{ Salinity } \\
\hline & & \multirow{2}{*}{$\begin{array}{l}\text { Con. }^{a} \\
\text { log } \\
\text { CFU/ml }\end{array}$} & \multicolumn{2}{|l|}{$\mathrm{pH} 2$} & \multicolumn{2}{|l|}{$\mathrm{pH} 3$} & \multirow{2}{*}{$\begin{array}{l}\text { Con. }^{\text {a }} \\
\text { log } \\
\text { CFU/ml }\end{array}$} & \multicolumn{2}{|l|}{$0.50 \%$} & \multicolumn{2}{|l|}{$1.00 \%$} & \multirow{2}{*}{$\begin{array}{l}\text { Con. }^{\text {a }} \\
\text { log } \\
\text { CFU/ml }\end{array}$} & 2 \\
\hline & & & $\begin{array}{l}\mathrm{log} \\
\mathrm{CFU} / \mathrm{ml}\end{array}$ & $\begin{array}{l}\mathrm{SR}^{\mathrm{b}} \\
(\%)\end{array}$ & $\begin{array}{l}\log \\
\mathrm{CFU} / \mathrm{ml}\end{array}$ & $\begin{array}{l}\mathrm{SR}^{\mathrm{b}} \\
(\%)\end{array}$ & & $\begin{array}{l}\log \\
\mathrm{CFU} / \mathrm{ml}\end{array}$ & $\begin{array}{l}\mathrm{SR}^{\mathrm{b}} \\
(\%)\end{array}$ & $\begin{array}{l}\mathrm{log} \\
\mathrm{CFU} / \mathrm{ml}\end{array}$ & $\begin{array}{l}\mathrm{SR}^{\mathrm{b}} \\
(\%)\end{array}$ & & l \\
\hline \multirow{2}{*}{$\begin{array}{l}\text { BIOPOP- } \\
1\end{array}$} & WT & $9.21 \pm 0.06$ & $4.54 \pm 0.04$ & $0.002 \%$ & $9.10 \pm 0.05$ & $78.18 \%$ & $8.32 \pm 0.03$ & $6.57 \pm 0.02$ & $1.75 \%$ & $N D^{c}$ & - & $9.20 \pm 0.02$ & $\varepsilon$ \\
\hline & ALE & $9.21 \pm 0.07$ & $5.80 \pm 0.01$ & $0.48 \%$ & $9.14 \pm 0.01$ & $83.13 \%$ & $8.89 \pm 0.08$ & $8.76 \pm 0.03$ & $71.82 \%$ & $4.36 \pm 0.06$ & $0.29 \%$ & $8.96 \pm 0.08$ & $\varepsilon$ \\
\hline \multirow{2}{*}{$\begin{array}{l}\text { BIOPOP- } \\
2\end{array}$} & WT & $9.12 \pm 0.1$ & $4.43 \pm 0.07$ & $0.002 \%$ & $8.97 \pm 0.08$ & $69.81 \%$ & $7.47 \pm 0.1$ & $4.78 \pm 0.06$ & $0.19 \%$ & $N D^{c}$ & - & $8.21 \pm 0.09$ & $\epsilon$ \\
\hline & ALE & $9.23 \pm 0.03$ & $6.95 \pm 0.01$ & $0.53 \%$ & $\begin{array}{l}9.19 \pm 0 . \\
003\end{array}$ & $91.76 \%$ & $9.18 \pm 0.03$ & $9.18 \pm 0.01$ & $98.91 \%$ & $6.62 \pm 0.08$ & $0.28 \%$ & $8.66 \pm 0.04$ & $\varepsilon$ \\
\hline
\end{tabular}

The viabilities are expressed as mean \pm

standard deviation.

a Con : Control,

cells under no

stress.

b SR : Survival

Ratio (\%)

c ND: not

detected

Table 2. Fatty acid compositions of S.thermopilus BIOPOP-1 and BIOPOP-2

\begin{tabular}{lllll}
\hline Fatty acids & \multicolumn{3}{l}{ BIOPOP-1 } & \multicolumn{2}{l}{ BIOPOP-2 } \\
\cline { 2 - 4 } & WT & ALE & WT & ALE \\
\hline C6:0 (\%) & 0 & 1.02 & 0 & 1.06 \\
\hline C16:0 (\%) & 18.72 & 14.79 & 14.87 & 20.24 \\
\hline C18:0 (\%) & 13.6 & 14 & 6.14 & 7.75 \\
\hline C20:0 (\%) & 9.45 & 14 & 2.05 & 1.74 \\
\hline C22:0 (\%) & 0.7 & 1.19 & 0 & 0 \\
\hline C18:1n9c (\%) & 18.74 & 16 & 24.6 & 21.04 \\
\hline C20:1 (\%) & 36.38 & 35.73 & 50.1 & 47.08 \\
\hline C22:1n9 (\%) & 2.41 & 3.27 & 2.23 & 1.09 \\
\hline Total & 100 & 100 & 100 & 100 \\
\hline SFA $(\%)$ & 42.47 & 45 & 23.07 & 30.79 \\
\hline UFA ${ }^{b}(\%)$ & 57.53 & 55 & 76.93 & 69.21 \\
\hline
\end{tabular}

a SFA: saturated fatty acid

b UFA: unsaturated fatty acid

\section{Figures}




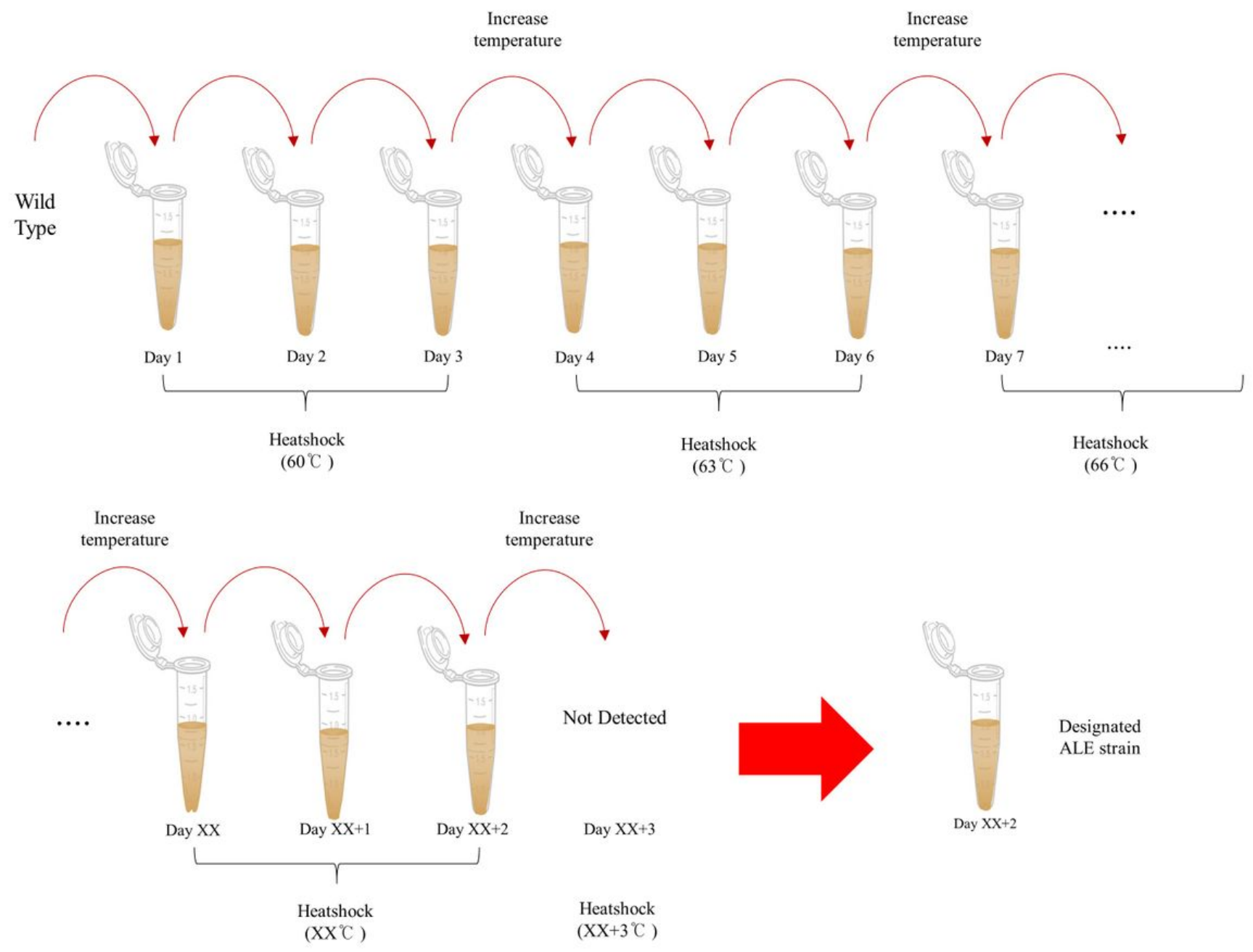

\section{Figure 1}

Procedure for adaptive laboratory evolution experiment. Temperatures was gradually increased from $60^{\circ} \mathrm{C}$ until strains were not detected. Heat shock time was 1 minute and then, cells were cooled down in room temperature for 5 min and incubated at $37^{\circ} \mathrm{C}$ for $24 \mathrm{~h}$. This procedure was repeated three times and increased temperature $\left(3^{\circ} \mathrm{C}\right)$. The final surviving bacteria were designated as ALE. 


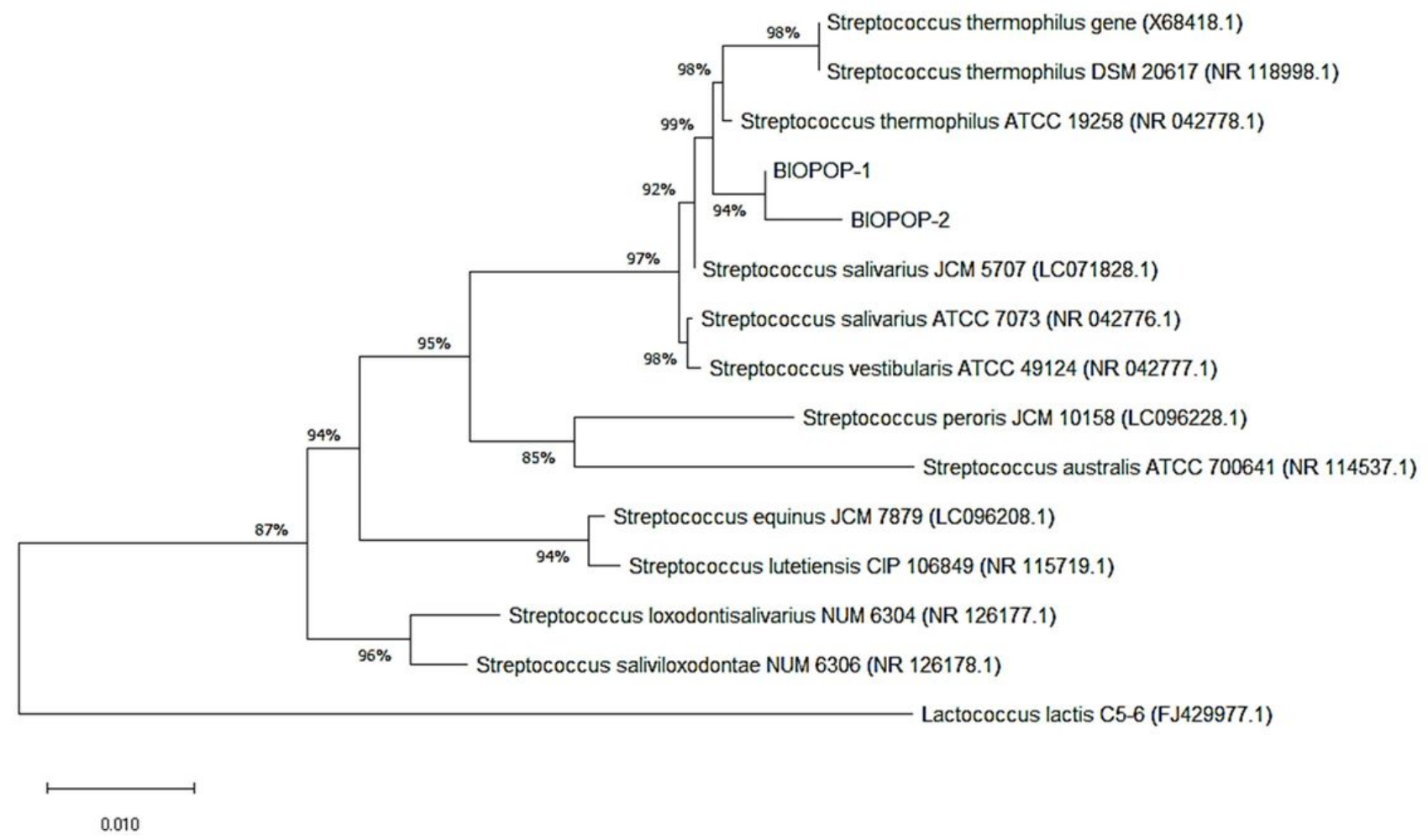

Figure 2

Neighbour-joining tree showing the phylogenetic relationships of strain BIOPOP-1, strain BIOPOP-2 and related type strains based on the 16S rRNA gene sequences. 16S rRNA gene sequence of Lactococcus lactis was used as out group. 
(a)

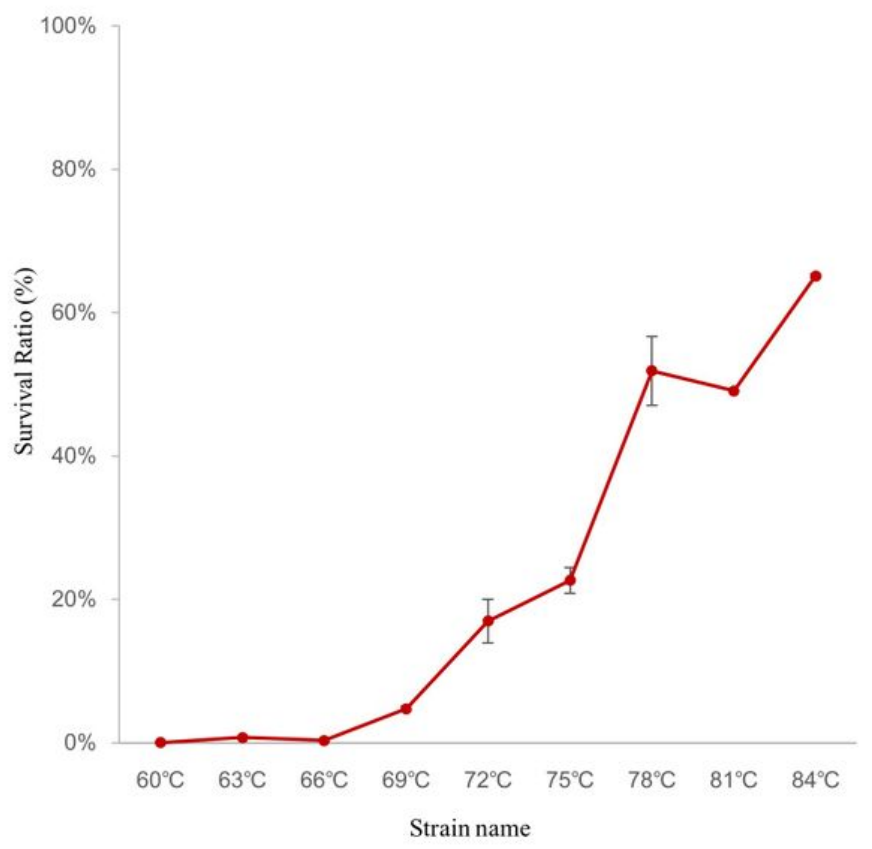

(b)

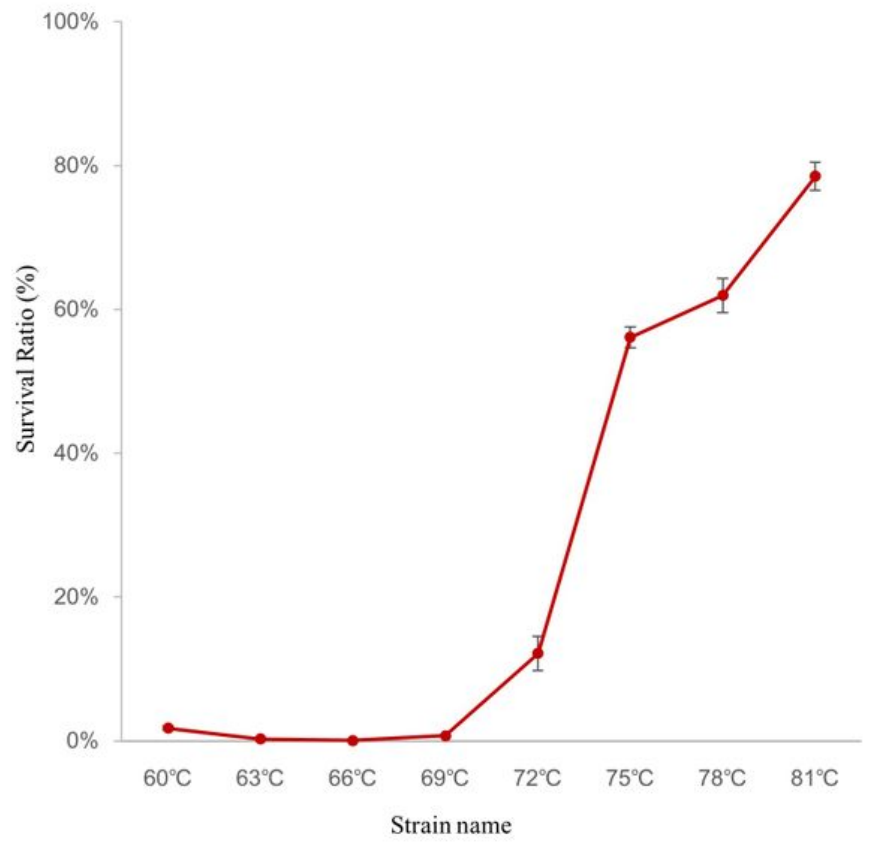

\section{Figure 3}

Enhancement of bacterial heat tolerance threshold. (a) BIOPOP-1, (b) BIOPOP-2. The error bars represented the calculated standard deviation of the measurements of three biological replicates. 
(a)

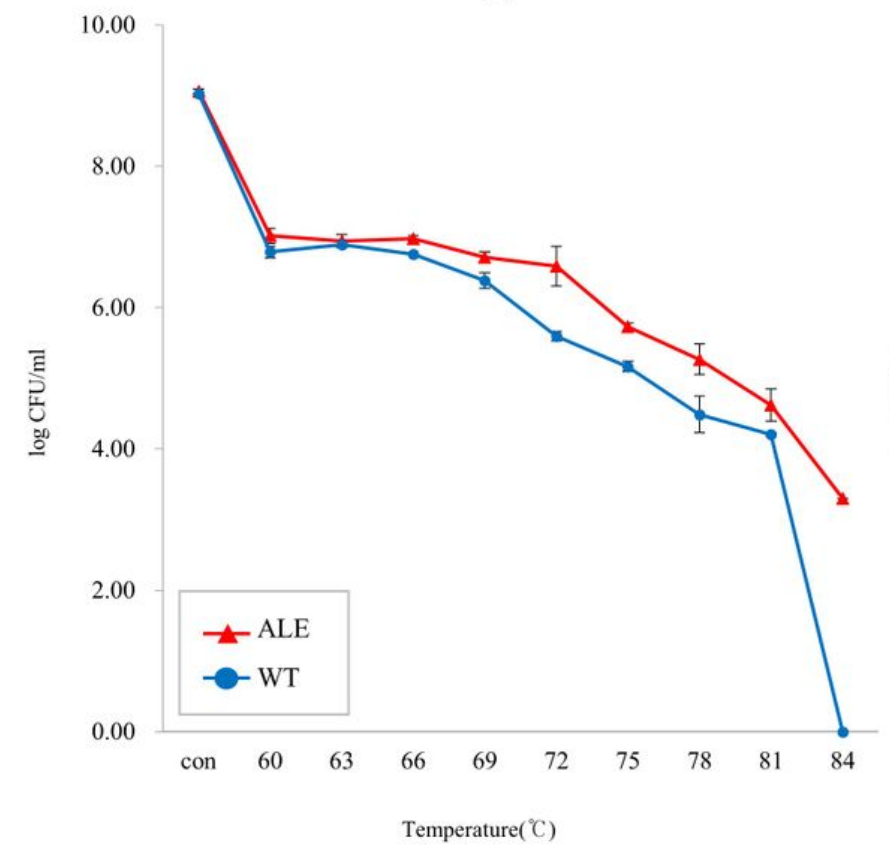

(b)

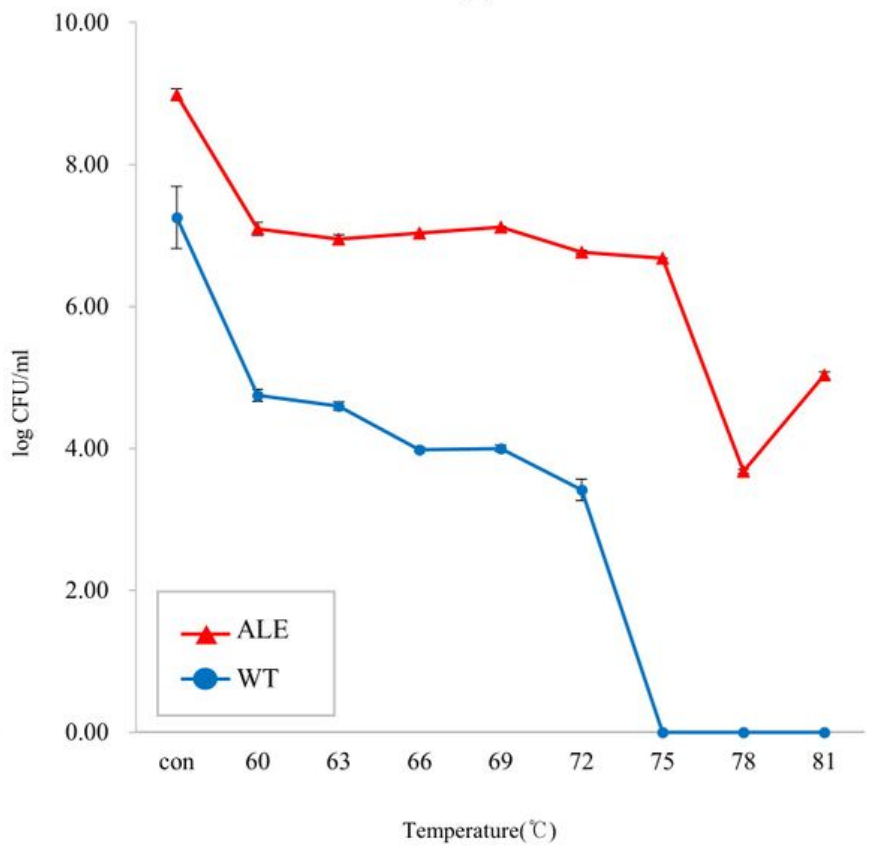

Figure 4

The results of heat treatment with variable temperatures at the set time. (a) BIOPOP-1, (b) BIOPOP-2. The error bars represented the calculated standard deviation of the measurements of three biological replicates. 
(a)

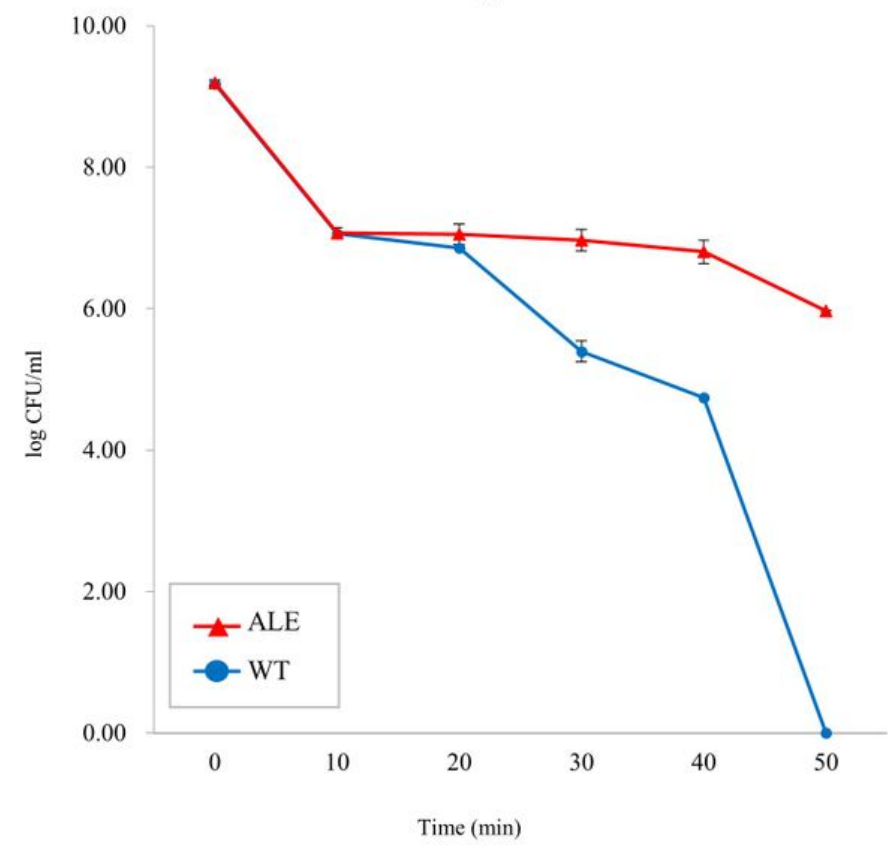

(b)

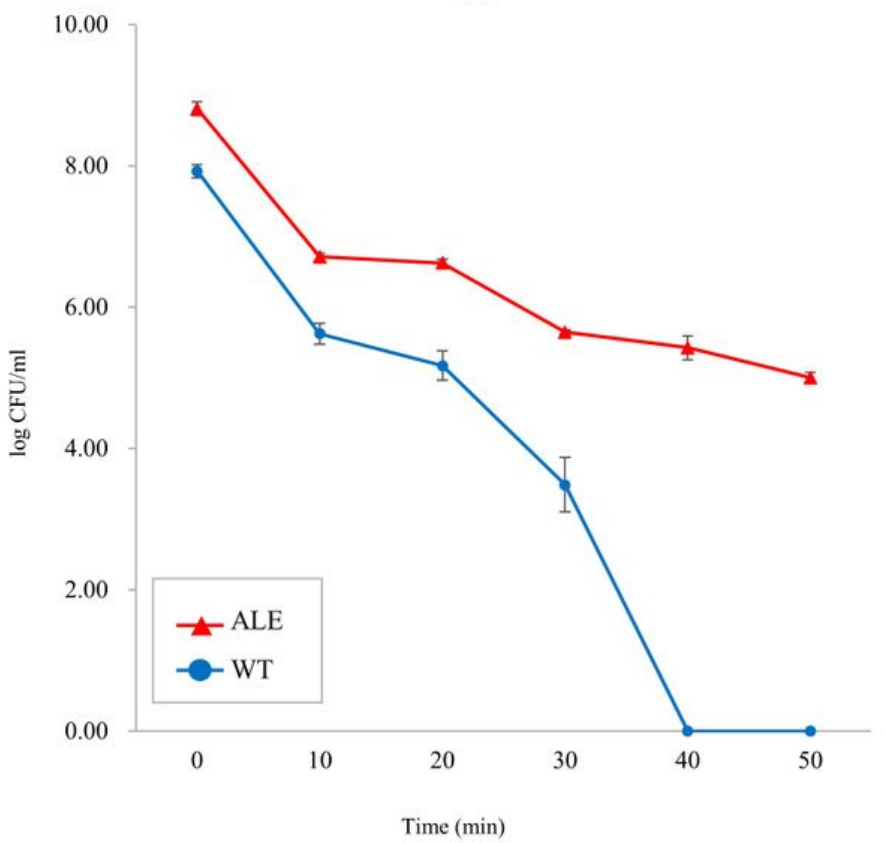

\section{Figure 5}

The results of prolonged heat treatment at constant temperature. (a) BIOPOP-1, (b) BIOPOP-2. The error bars represented the calculated standard deviation of the measurements of three biological replicates 
(a)

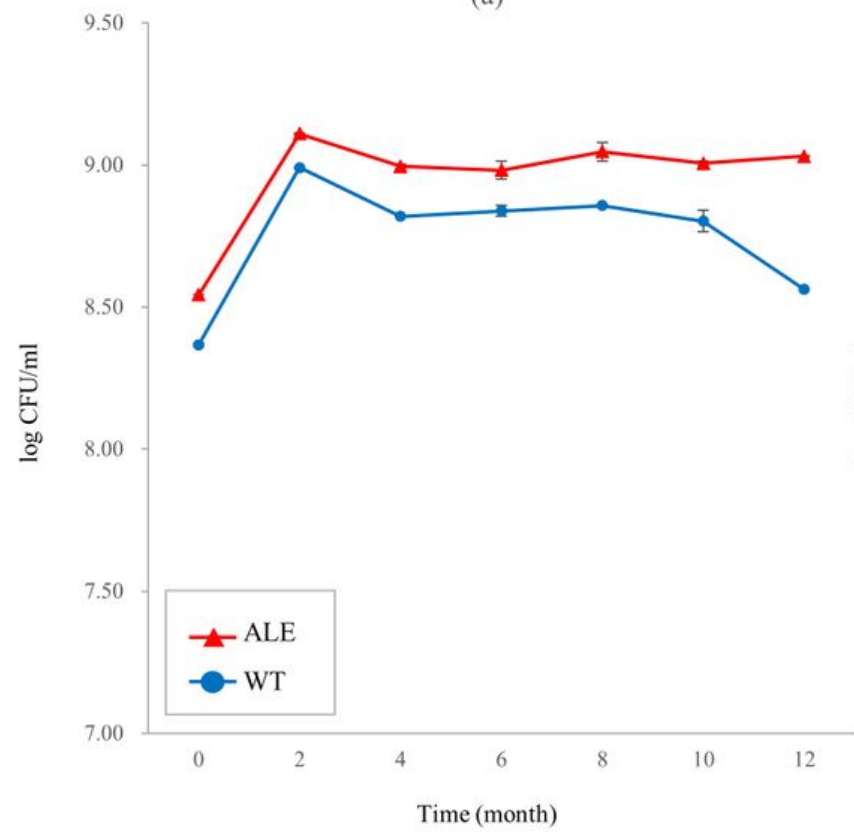

(b)

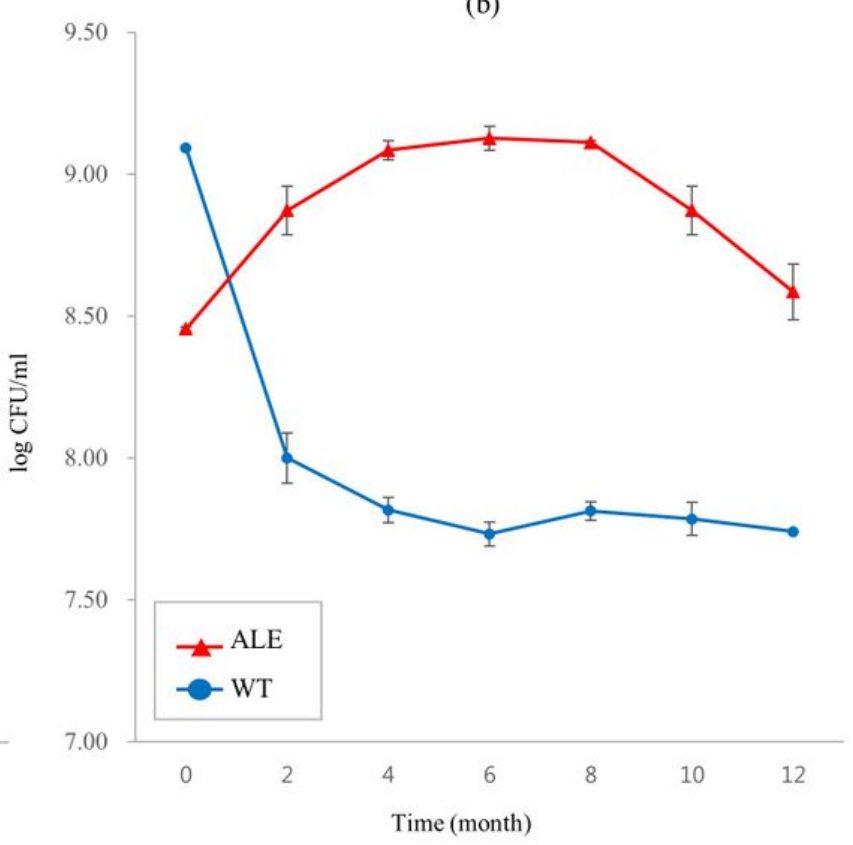

\section{Figure 6}

Stability to freezing and long-term storage in frozen state of S. thermophilus BIOPOP-1 and BIOPOP-2. (a) BIOPOP-1, (b) BIOPOP-2. The error bars represented the calculated standard deviation of the measurements of three biological replicates.

\section{Supplementary Files}

This is a list of supplementary files associated with this preprint. Click to download.

- SupplementaryTable.xls 